\title{
Worsening British views of China in 2020: evidence from public opinion, parliament, and the media
}

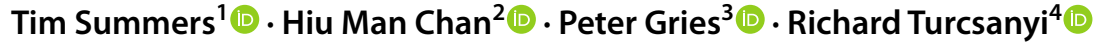

Received: 21 June 2021 / Revised: 5 September 2021 / Accepted: 9 September 2021/

Published online: 1 December 2021

(c) The Author(s), under exclusive licence to Springer-Verlag GmbH Germany, part of Springer Nature 2021

\begin{abstract}
How did Britons view China in 2020, at the height of the Covid-19 pandemic? This paper presents new, detailed evidence of the negative and worsening perceptions of China in the UK across three domains: public opinion (based on survey data collected in autumn 2020), political elites in parliament, and the media. The worsening of perceptions of China emerged in the context of a changing and more contested China policy from the UK government and a greater level of public debate about China, partly a consequence of the onset of the Covid-19 pandemic. The paper places analysis of these perceptions in the context of the development of relations between the UK and China. Together with deteriorating Chinese views of the UK's China policy and controversy over a number of developments in China, widespread negative views about China among the British public and in political circles will constrain UK-China relations from developing in a more positive direction.
\end{abstract}

\section{Introduction}

How did Britons view China in 2020, at the height of the Covid-19 pandemic? This paper presents new, detailed evidence of the negative and worsening perceptions of China in the UK across three domains: public opinion (based on survey data collected in autumn 2020), political elites in parliament, and the media. This happened in the context of a changing and more contested China policy in the UK and a

Tim Summers

summers@cuhk.edu.hk

1 Centre for China Studies, The Chinese University of Hong Kong, Hong Kong, SAR, China

2 Creative \& Cultural Industries, De Montfort University, Leicester, UK

3 Manchester China Institute and Professor of Politics, The University of Manchester, Manchester, UK

$4 \quad$ Palacky University Olomouc, Olomouc, Czech Republic 
greater level of public debate about China, partly a consequence of the onset of the Covid-19 pandemic.

We place this analysis in the context of the historical development of relations between the UK and China. In the years following the UK's recognition of the PRC in 1950, relations were substantially shaped by Cold War dynamics (Mark 2017). For much of the latter part of the twentieth century, the relationship was dominated by the question of Hong Kong's return to Chinese sovereignty in 1997. Moving into the twenty-first century, Hong Kong was no longer a key bilateral issue, and SinoBritish relations entered a new, improved period under Tony Blair's Labour government from 1997 onwards (Brown 2011). Shaun Breslin (2004) has argued that this period was marked by a British policy which emphasised economic engagement and efforts to encourage political and social change in China. As recently as 2015, then chancellor (finance minister) George Osborne promised a "golden decade" in UK-China economic relations, though policy towards China remained contested domestically.

Recent scholarship has explored different aspects of UK-China relations. Scott Brown (2018a) examines the British government's China policy from 2010 to 2016, arguing that the emphasis on economic ties ("free trade") grew during that period, while the ideological dimension to British China policy declined. Peter Harris (2017: 265) covers the same period, but with a focus on the role that China and policy towards it played in domestic British politics, arguing that the main political parties "weaponised" China in different ways: the Conservatives used it "to facilitate a macro-economic policy that de-emphasised the role of the state as a way to plug gaps in the government's fiscal agenda and as a powerful symbol of the benefits of economic openness", while Labour "tended to vilify China as a demon of globalisation in order to gin up popular enthusiasm for a more left-wing policy". This highlights the potential for a contested China policy in the UK.

As Harris argues, this dynamic partly reflects the growth in China's influence, and shifts in the relative distribution of power between the UK and China are a major theme of Kerry Brown's prolific writings about the bilateral relationship. Much of this has straddled the academic and policy worlds, with Brown's recent book (2019) arguing that the UK is not prepared to deal with China as a major power. Brown also identifies Chinese interests in its relationship with the UK, including finance, technology, and investment, similar to those identified by Irwin Crookes and Farnell (2019), whose analysis also reflects a new phase of the literature on Sino-British relations in dealing explicitly with the impact of Brexit. They argued that the UK's post-Brexit China policy would face considerable constraints, from London's continued need to manage its relationship with the EU, to US interests and pressure, and British domestic politics, partly driven by human rights and national security considerations. In a similar vein, Summers (2021a) demonstrates how the British government's China policy became more critical of China between the June 2016 Brexit referendum and the actual departure from the EU in January 2020, and separately highlights the impact of US-China rivalry on UK-China ties, and the growing controversy over Hong Kong (Summers 2019, 2021b). George Osborne's departure from government in 2016 removed one of the key advocates of closer ties with China. 
Policy papers on UK-China relations have also increased, especially after 2019. These have tended to combine analysis with policy recommendations or lobbying based on particular interpretations of developments in China and their external implications. Prominent themes have related to human rights, Hong Kong and Xinjiang, the South China Sea, allegations of Chinese "interference" in British politics, and critical national infrastructure, in particular the role of Huawei (before the British government's volte face in July 2020 led to the gradual removal of that company's equipment from the UK's 5G network), as well as concerns about infiltration or espionage by Chinese academics and business people. These topics have shaped recent British public debate about China, actively driven by some politicians, think tank researchers, and parts of the media (McCourt 2021: 3) and featured in the growing US hostility towards China during the Trump presidency, and in China debates in other Western countries. Table 1 sets out a timeline of some of the key developments in the UK's policy, which reflect the "longstanding economic opportunity frame [being] increasingly challenged by a national security frame" (McCourt 2021: 1).

In the context of dealing with Covid-19 and Brexit, the British government responded gradually to the growing contention over China policy, with then Foreign Secretary Dominic Raab saying in April 2020 that the relationship could not return to "business as usual". The debate over what that should mean continued unresolved at least until March 2021, when the government issued its long-awaited Integrated Review of Security, Defence, Development, and Foreign Policy. This set out some broad parameters for China policy: in what appeared like an effort to balance different policy elements, the Review characterised China as a strategic challenge for the UK, while emphasising the need to engage with China for economic reasons and to pursue policy goals in global governance such as in relation to climate change (HM Government 2021).

How does the wider British public view China, and what are the implications of public opinion for UK China policy? As change and uncertainty continue to characterise the relationship into the future, this paper responds to this gap with a timely analysis of public views of China. It goes wider than the perceptions of policymakers, which have been studied in more detail elsewhere (Summers 2021a; Brown 2018b). Theoretically, the paper contributes to public opinion and foreign policy analysis literature which identifies an important role for public perceptions and domestic politics in the making of foreign policy (Gries 2014). This speaks to the idea that foreign policy making reflects interactions between multiple actors, and that policy decisions are informed at least partly by the way that issues are framed (Brown 2018b). ${ }^{1}$ Public and media perceptions both reflect dominant framings and can shape the perceptions adopted by policy elites. The paper also contributes to studies of Western "images" of China, which have historically "tended to accord with, rather than oppose, the interests of ... the governments of the day" (Mackerras

\footnotetext{
${ }^{1}$ Framing is "selecting and highlighting some facets of events or issues, and making connections among them so as to promote a particular interpretation, evaluation and/or solution" (cited Sparks 2010: 352).
} 
1987: 263), and points to the need for further studies of the different ways in which public opinion about China is formed in the UK.

The paper adopts a mixed methodology to examine public, media, and parliamentary perceptions of China in 2020. Analysis of public perceptions is primarily based on data produced by the Sinophone Borderlands survey of public perceptions of China in 13 European countries (Turcsanyi et al. 2020), carried out during September and October 2020 on a representative research sample with respect to gender, age, education levels (primary-secondary-tertiary), country region of residence (NUTS 3), ${ }^{2}$ and settlement density (low-medium-high). The data was collected online by NMS Market Research agency. Altogether, 19,673 European adults aged 18-70 were included in the survey, of which 1500 were from the UK (additionally, 139 British respondents were deleted by the agency during the standard process of data cleaning). The respondents were drawn from on-line panels according to the quota scheme following the national demographic statistics. The next section of the paper analyses the survey data on British public perceptions of China, in particular the Covid factor and the relevance of ideological and political preferences on British views of China. This is followed by analysis of parliamentary debates on China in 2020 and some brief discussion of British media coverage of China in 2020. The conclusion summarises the key findings and returns to the wider questions of UKChina relations, with a focus on the implications of deteriorating British views of China for the future of UK-China relations.

\section{Public perceptions of China: 2020 survey data}

Until recently, there was relatively little survey data on British public perceptions of China. One exception was Chow et al. (2019), who analysed a 2018 convenience sample of mostly female and highly educated Britons. They argued that supporters of Leave (measured indirectly by "aversion to the EU") tended to have more negative perceptions of China and were more suspicious of China as a military threat, whereas those with a Remain identity had a more positive outlook on China's global role and preferred closer engagement.

More recent and representative national surveys suggest that perceptions of China have worsened since 2018. In May 2020, YouGov (2020) found that $47 \%$ of 2258 British respondents saw "China becoming a superpower" as "more of a threat" with only $11 \%$ seeing it as "more of an opportunity". The Pew Research Center's 2020 global poll on attitudes towards China found that, in the UK, 74\% had an "unfavourable" opinion of China and $22 \%$ a "favourable" opinion (compared to 55\% and $38 \%$ respectively in 2019). This change was one of the two largest year-on-year declines in public sentiment in their survey of 14 countries (Silver et al. 2020). The latest British Foreign Policy Group survey revealed that China was seen as "distinctively hostile", with "only a fifth of Britons now supporting any form of UK-China economic relationship" (British Foreign Policy Group 2021).

\footnotetext{
${ }^{2}$ NUTS 3 is a classification of small regions for statistical analysis.
} 
Table 1 Timeline of key recent events in British China policy

- 2015: Xi Jinping's state visit to the UK marks a "golden era" (formally a "global comprehensive strategic partnership for the twenty-first century") ${ }^{\mathrm{a}}$

- 2017-18: Growing debate in UK policy circles about whether there should be a rebalancing in policy towards China

- 2019: Hong Kong social unrest contributes to British perceptions of an authoritarian turn in Beijing. Intensification of British public discussion of developments in Xinjiang

- 2020: Covid-19 first identified in Wuhan, spreading in significant numbers to the UK and contributing to a growth in critical public views towards China

- 2020: After initially reconfirming its engagement with Huawei in January, the British government announced in July that Huawei would not be allowed to remain in the UK's 5G infrastructure after 2027 (though it could operate in other areas)

- 2020 (May): Announcement of National Security Law for Hong Kong in response to social unrest of 2019 leads London to take a position of strong opposition to Beijing's approach to Hong Kong, including announcing a "pathway to citizenship" for holders of British National (Overseas) passports and their dependents

- 2021 (March): UK sanctions Chinese officials in response to reports of human rights abuses in Xinjiang, leading Beijing to sanction a number of parliamentarians, the Conservative Party's China Research Group, an academic and a barristers chambers

a (Available at https://www.gov.uk/government/news/uk-china-joint-statement-2015)

The 2020 Sinophone Borderlands survey revealed overall negative public perceptions of China in the UK: $62 \%$ reported "negative" or "very negative" sentiment, and $68 \%$ said that their "general view" of China had worsened over the last three years, the highest of the 13 countries surveyed (Fig. 1). Britons only viewed Russia and North Korea more negatively than China.

This survey allows us to dig deeper into the complexity of public attitudes towards China to paint a more nuanced picture. The rise of China as a great power was seen as equally negative to the general image of China, while the perceptions of Chinese people and Chinese technology were about 15 percentage points more positive (and overall neutral rather than negative). Many other aspects of China, however, were seen negatively, including trade with China, Chinese investments, and the Belt and Road Initiative (a Chinese connectivity initiative). The most negative perceptions were of the Chinese military, China's influence on democracy in other countries, and China's impact on the global environment.

In terms of British foreign policy priorities in relation to China, the survey showed that addressing cyber security, promoting human rights and democracy in China, and cooperation on global issues were somewhat more important to respondents than intellectual property rights, preventing China's geopolitical expansion, and promoting trade and investment. This shows that economic diplomacy is certainly not the top concern for the British public in terms of China, yet people are also not in the mood for geopolitical struggle. Still, they hold strong concerns about cybersecurity and human rights, while seeing the need to cooperate with China on global governance.

Age was a major driver of China attitudes, with older Britons much more negative towards China than younger Britons. Age alone accounted for $10 \%$ of the variance in China attitudes. Dissatisfaction with the global environment also explained 
nearly $3 \%$ of additional negativity towards China beyond standard demographic covariates (a small but significant finding). Other factors did not have a significant explanatory power (political preference and ideology are considered below).

The survey included a word association question. After introductory questions to ascertain the demographic profile of respondents, but before proceeding to other questions about China, respondents were asked the open-ended question, "What first comes to mind when you hear about China?" Fig. 2 displays the results in a word cloud, with the frequency of words (including closely related responses) represented by the font size of the word. "Covid-19" was by far the most frequently entered response, followed by "communism."

We also coded each response (hereafter "word association") either "positive", "negative", or "neutral", with a small number of cases coded both positive and negative to reflect multiple answers which differed in the image they presented, though almost all the responses could clearly be assigned to one of the three categories. ${ }^{3}$

Words or phrases with negative associations made up over $80 \%$ of the 1500 responses. This is significantly higher than the $62 \%$ who reported "negative" or "very negative" feelings towards China and the $68 \%$ who said that their feelings towards China had worsened over the past three years. Only 109 (7\%) word associations were positive, significantly less than the $19 \%$ who reported "positive" (14\%) or "very positive" (5\%) feeling towards China in a subsequent survey question. A total of $159(10 \%)$ word associations were neutral, compared to $19 \%$ who said they had neutral feelings about China in the subsequent survey question.

Overall, therefore, respondents were more likely to come up with negative phrases when they first think of China than to say that they have negative feelings about China. Other negative perceptions relate to more contemporary political themes: Covid-19, "authoritarianism", "lack of freedoms", Hong Kong and Xinjiang. While overall, analysis of the word associations shows negative perceptions are by far the most common, positive word associations were connected to China's culture, sometimes explicitly described as "traditional culture", and its history and traditions, food (there are a couple of references to rice, but tea is not mentioned), ${ }^{4}$ and technology. ${ }^{5}$ The Great Wall is mentioned on numerous occasions. There were very few positive word associations outside these categories. ${ }^{6}$

\footnotetext{
${ }^{3}$ This coding was based on the adjectives used and the images identified, with Covid-19 (or some variant) common and coded negative. Numerous political terms with negative connotations featured (see Fig. 2). This incorporates some assumptions. For example, "communism" was coded as negative given its usual negative connotations in the British context. "Technology" was generally coded positive (see note below). Whereas "strength" was coded positive, "power" was generally coded negative.

${ }^{4}$ A small number of references to food were coded negative, for example "weird food". Otherwise, in this discussion "food" is taken a reference to Chinese food as a cuisine, sometimes made clear in phrases such as "good food". We have not included among the positive coding apparently negative references to Chinese eating habits such as "the Chinese eat everything", etc.

${ }^{5}$ In cases where technology is described as a threat, for example, this would be coded negative. But most references to technology were either the one word "technology" (which was coded positive), or implied a positive view (e.g. "advanced technology").

${ }^{6}$ Some of the word associations suggest a lack of clarity over what is Chinese. For example, "sushi" and "chicken curry" were both mentioned, as were "anime", "kimonos", and "k-pop". There were a small number of exceptions to these positive views of culture, such as "quite culturally out of date". The lack of
} 


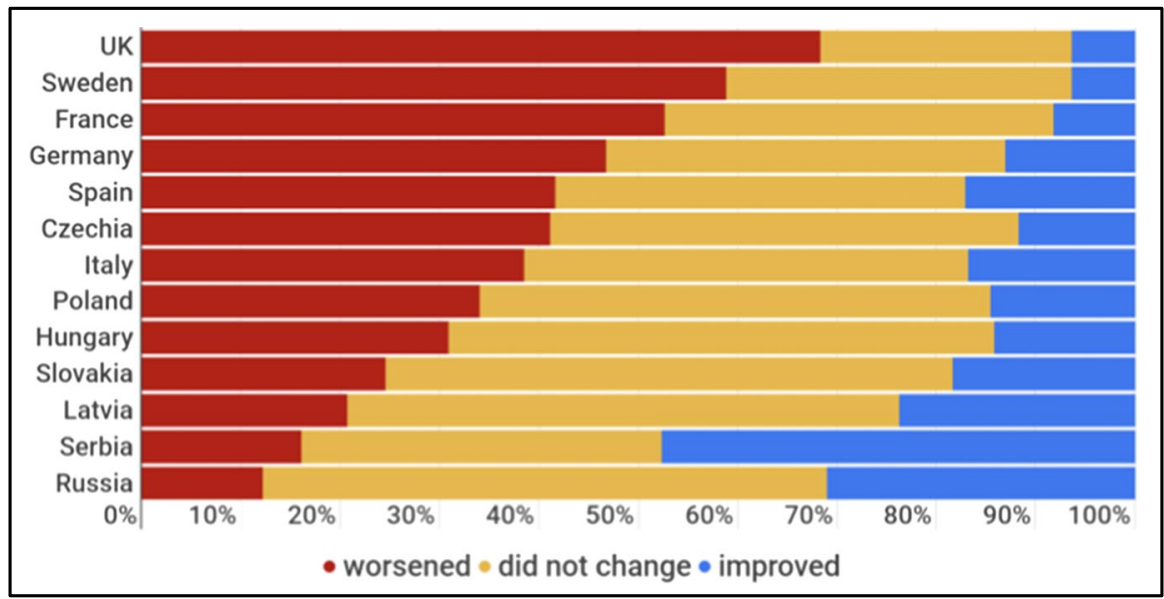

Fig. 1 Change of feeling towards China among Europeans in the past three years (\% of respondents)

\section{The Covid-19 factor}

Covid-19 (or equivalent terms such as "pandemic" or "coronavirus") was the first word association of 291 respondents (almost one-fifth of the total and more than for any other European country surveyed apart from France). ${ }^{7}$ This suggests that, unsurprisingly, the Covid-19 pandemic may have been a particular factor in perceptions of China recorded in this survey in September and October 2020. This was about six months after the number of recorded coronavirus cases began to rise rapidly in the UK, prompting a flurry of reports and commentary criticising China for spreading the virus (Foreign Affairs Committee 2020; Henderson et al 2020; Patten 2020), and a spike in public interest in China in the UK. ${ }^{8}$

The survey also produced some specific data on perceptions of the relationship between China and Covid-19. Respondents saw China as slightly more helpful to the UK during Covid-19 than Russia but less helpful than the USA and EU, with a mean score of 3.06 (scores out of 10; Russia, USA, and EU mean scores were 2.79, 3.81, and 4.97 respectively). When asked about the origins of Covid-19, the highest level of agreement was to the statement that it "spread due to Chinese eating bats and other wild animals" (mean score 4.44 on a 1-7 scale with 4 as the scale midpoint, and $7=$ strongly agree), followed by "accidental escape from a laboratory in China" (4.00), it "jumped naturally from humans to animals" (3.96), "artificially made in a

\footnotetext{
Footnote 6 (continued)

reference to "tea" or "Chinese tea" is interesting given the self-image of tea as a key feature of Chinese culture, and even the advocacy of "tea diplomacy" by some in the Chinese foreign policy establishment.

7 We are grateful to Kristina Kironska for her comparative analysis of the survey results across countries.

8 Data from Google Trends suggests that interest in China peaked in March 2020 and may have declined in the second half of 2020, returning to pre-COVID-19 levels; see https://trends.google.com/trends/explo re?date $=$ today $\% 205-y \&$ geo $=$ GB\&q $=$ China .
} 


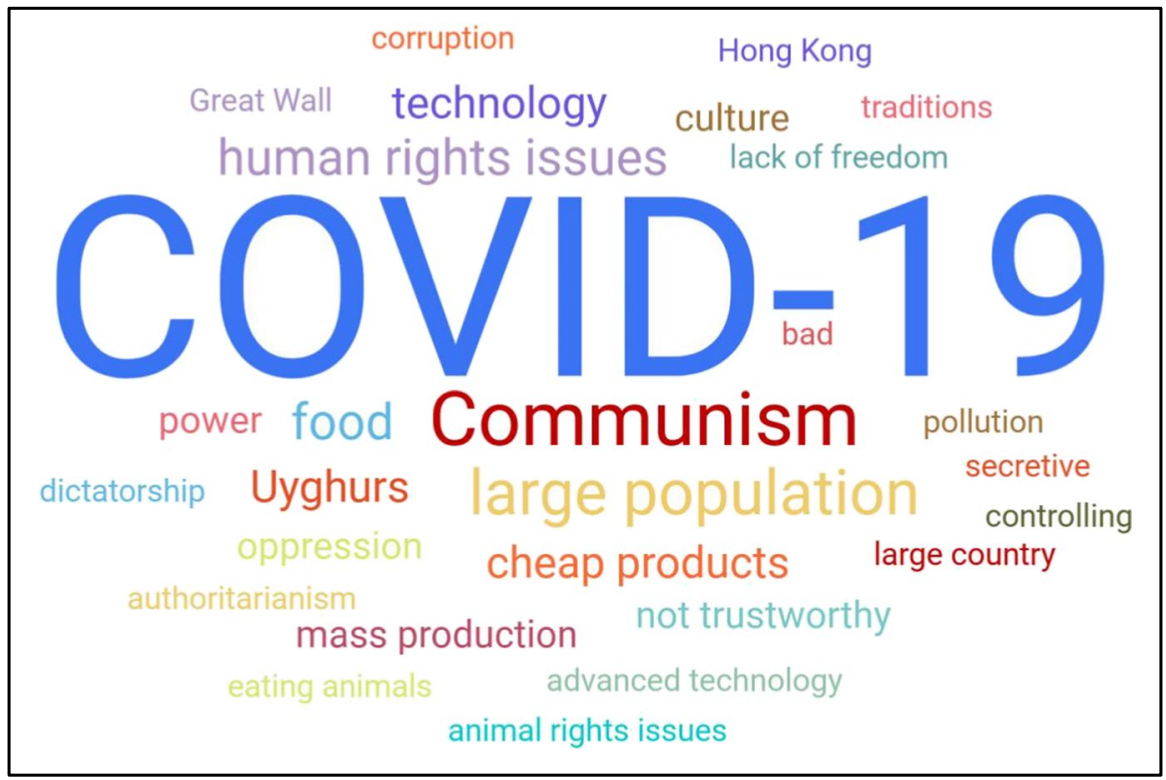

Fig. 2 Word cloud showing first responses when asked about China

Chinese laboratory and spread intentionally" (3.83), and much lower average scores for "brought to China by the US military in 2019" (2.88) and "spread due to the 5G network" (2.15). Analysing this data further shows that the belief that Covid19 originated in a Chinese laboratory and was intentionally released explains $2 \%$ of additional negativity towards China beyond the standard demographic covariates of age and gender; this is a small but statistically significant finding. ${ }^{9}$

\section{How Brexit identities and ideology shape attitudes towards China}

In our 2020 sample, Brexit voters were divided over China (Fig. 3). On a 0-100 feeling thermometer towards China, on average Leave voters felt $9^{\circ}$ more negatively towards China than did Remain voters, ${ }^{10}$ controlling for gender, age, and education. In our survey, Leavers also claimed that their views of China had worsened even more over the past three years than did Remainers, ${ }^{11}$ again controlling for gender, age, and education. Leavers are likely a big reason why the UK (of all 13 European countries surveyed) ended up having the most respondents claiming that their views of China over the previous three years had worsened.

\footnotetext{
$9\left(F_{1,1489}=31.86, p<.001 ; R^{2}=.02\right)$.

${ }^{10}$ For Leave voters, $N=628, M=39^{\circ}, \mathrm{SD}=26$; for Remain voters, $N=548, M=30^{\circ}, \mathrm{SD}=24$, $F_{1,1171}=21.06, p<.001 ; \eta_{p}^{2}=.02$.

${ }^{11} F_{1,1171}=26.38, p<.001 ; \eta_{p}^{2}=.02$.
} 
Further analysis revealed no direct effect of political ideology (measured with a scale averaging left-to-right and liberal-to-conservative self-placements) on British attitudes towards Chinese foreign and human rights policies (represented in the faint flat dotted line in Fig. 4). ${ }^{12}$ A regression analysis controlling for age, gender, and education level confirmed this visual intuition. ${ }^{13}$ On average, the British Left and Right maintain equally negative views of Chinese policies. ${ }^{14}$

Brexit does not have a direct effect on attitudes towards Chinese foreign and human rights policies either. Leave voters $(N=628, M=5.50)$ were only marginally more negative than were Remain voters $(N=548, M=5.10) .{ }^{15}$

Figure 4 presents the results of a statistical analysis in which Brexit vote choice moderates the impact of ideology on attitudes towards Chinese foreign and human rights policies. It reveals a statistically significant disordinal interaction: both slopes were statically significant, but in the opposite directions, cancelling each other out at the full sample level, as discussed above. Leave voters (the dashed, rising line) were the most negative about Chinese policies on the Right, and the least negative on the Left. The pattern was reversed for Remain supporters (the solid, downward line): the Left was more negative than the Right. The biggest cleavage, furthermore, was within the Right, with Leave voters the most negative on the Right, and Remain voters the most positive. This could reflect a cleavage between anti-immigrant and pro-free trade segments of the British Right.

Where do British views of China come from? To explore further the context in which public opinion is shaped, and how the debate about China is framed, we look in detail at parliamentary debates on China in 2020, followed by a brief discussion of select media coverage of China in the UK.

\section{Political and parliamentary debates over China in 2020}

This analysis of British public opinion raises the question of whether there is a significant difference in perceptions of China between parliamentarians from different parties. We assessed this by collating data on the party affiliation of members of both houses of parliament (the Commons and the Lords) who spoke in debates on China in 2020, ${ }^{16}$ and undertaking a qualitative assessment of whether the views they expressed towards China were favourable or unfavourable, based on a careful

\footnotetext{
12 Substituting Labour vs Tory party identity for this political ideology measure produces similar results, but they are only statistically marginal because the binary PID variable is not as robust as the political ideology scale.

$13 B=-.01, p=.68$. Of the covariates, only age was statistically significant, with older (vs. younger) Britons much more negative towards Chinese policies. Indeed, age alone accounted for $10 \%$ of the variance in attitudes.

14 The full sample mean (5.19) was 1.19 above the scale midpoint of 4, a large difference statistically, $T_{1499}=33.00, p<.001$, Cohen's $d=.85$. Cohen (1988) considered $d=0.2$ be "small," 0.5 "medium," and 0.8 "large" effect sizes.

${ }^{15} F_{1,1171}=3.23, p=.07, \eta_{p}{ }^{2}=.003$. Following statistical convention (Cohen 1988), a "partial eta squared" $\left(\eta_{p}{ }^{2}\right)$ of .01 is considered small, .06 medium, and .14 large.

16 The new House of Commons (lower house of parliament), elected in the general election of December 2019 , began sitting at the beginning of 2020 , so this sampling also marks the beginning of a new parliamentary term.
} 


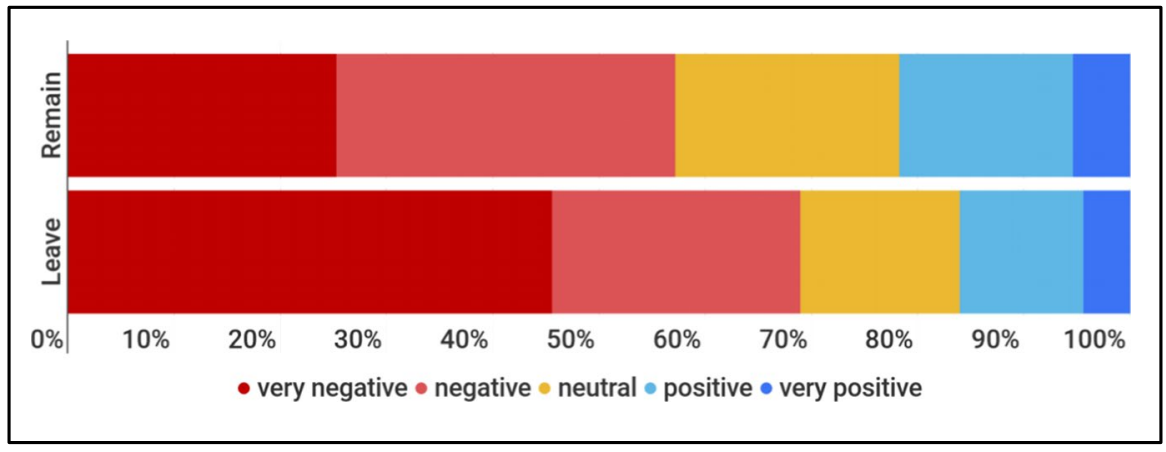

Fig. 3 Feelings towards China according to the respondents' preference about Brexit

reading of the transcripts of these debates. In 2020, there were 39 debates on China in both chambers, an increase from 30 in 2019, and a significant increase on the historical number of debates before 2019 (see Fig. 5). ${ }^{17}$ In 2020, 18 of these debates were on Hong Kong, compared to 19 in 2019. Other than Hong Kong, the issue covered most extensively during 2020 was Xinjiang, and there was significant discussion of Tibet, the South China Sea, and Taiwan (see Table 2 for details of debate topics). Other issues relating to China, including the global economy and climate change, hardly attracted any attention in these debates.

A careful reading of the transcripts clearly reveals an overwhelming predominance of "unfavourable" views of China. Throughout the year, we identified only one neutral intervention in the Commons and nine in the Lords (five of which were in relation to Hong Kong). ${ }^{18}$ Other interventions were strongly critical of China and/ or called for a shift in British government policy towards what could be described as a more "hawkish" approach. On Xinjiang, for example, there were consistent calls for the government to introduce targeted sanctions in response to developments in that part of China, something that the government eventually did in March 2021. On Hong Kong there have been similar calls, though it is also worth noting that while

\footnotetext{
17 We identified debates by using the Hansard website "search for debates" function for the years 2008 to 2020 inclusive, with keywords: China, Taiwan, Xinjiang/Uyghurs, Tibet, Hong Kong. This also picks up some ministerial statements and questions, including those without any debate or with only a few interventions, and may miss some debates in which China featured prominently but were presented as being about critical national infrastructure, for example. But it gives a good set of time series data and a good sample for our analysis of parliamentary perceptions of China in 2020.

18 In the Lords, these were comments on Hong Kong by Lord Howell (4 June and 29 June), Lord Wilson (4 June), Lord Carrington (19 March), Lord Powell (4 June), a question on supply chains by Lord Erroll (1 July), a question on whether the government still aimed for a trade deal with China by Baroness Henig (22 July), and an intervention about collaboration on vaccine development by Lord Campbell-Savours (22 July). In the Commons, Conservative MP Richard Graham, who spoke in a couple of debates, made the most nuanced comments (Graham is the Chair of the All Party Parliamentary Group on China and probably one of the most knowledgeable MPs when it comes to China).
} 


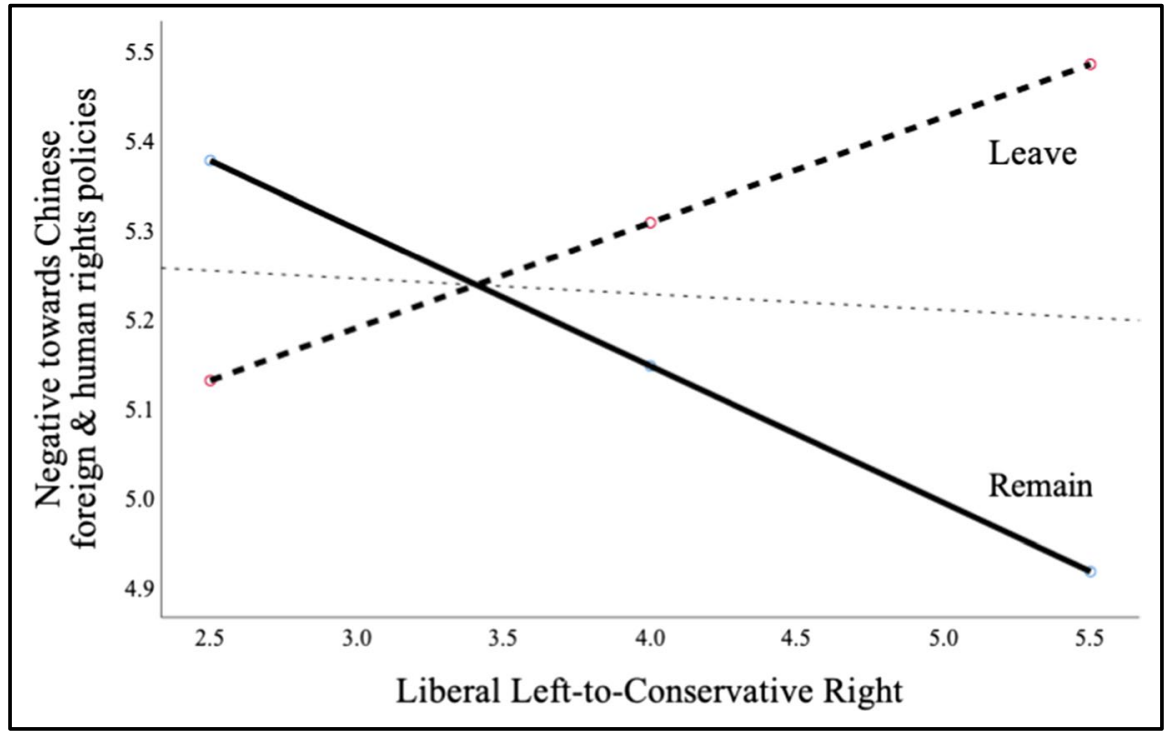

Fig. 4 Brexit and political ideology interact to shape attitudes towards Chinese foreign and human rights policies, with Leave voters on the UK Right the most negative, and Remain voters on the UK Right the most negative

parliamentarians were very critical of Beijing's policy towards Hong Kong and in particular the introduction of its National Security Law, they were-at least for several months during the summer of 2020-positive about the British government's response to that legislation, especially the decision to introduce a "pathway to citizenship" for holders of British National (Overseas) passports and their dependents. ${ }^{19}$

The lack of positive or favourable views on China expressed in these debates is striking. There are parliamentarians who have a more positive view of China, and it may be that they chose not to participate in what were consistently very one-sided sessions. ${ }^{20}$ In the Commons debates during 2020, a total of 147 of the 650 Members of Parliament (MPs) spoke either to raise a question or to make a longer intervention (not including responses from government ministers), with 52 of these speaking on more than one occasion. That means that $27 \%$ of non-ministerial MPs spoke in

\footnotetext{
19 This positive mood has soured since, with an increase in pressure on the government to "do more" on Hong Kong. The BN(O) scheme came in for slightly more pointed questioning in the Lords than the Commons, but was supported by a clear majority of those speaking in both Houses.

20 A recent piece by Quartz media on British "China watchers" (18 May 2021, available at https://qz. com/se/profiles-in-influence-meet-the-uks-china-watchers/) suggests that Richard Graham MP, Mark Logan MP, and Lord (James) Sassoon are more positive about China, for example. On the Xinjiang issue, Sassoon commented in his interview for that piece that "the atmosphere has been so unpleasant in and around Westminster in the last year that I prefer to write to ministers on trade topics and do what I can in a small way to influence the direction of trade policy and the engagement of China, and trying to keep lines open to China".
} 


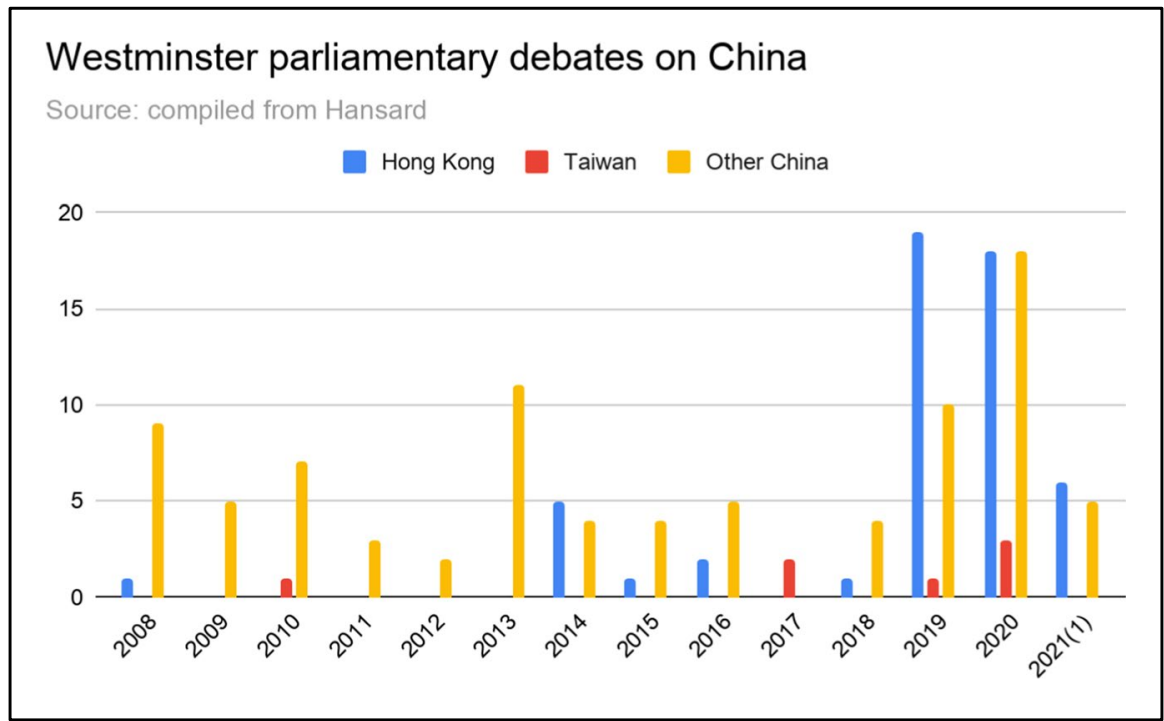

Fig. 5 Westminster parliamentary debates on China

a China debate during 2020 (ministers, of whom there are 102 in the Commons, would not speak unless representing the government in that debate). ${ }^{21}$

Further analysis of party affiliation of those speaking in these debates shows that, in the Commons, the proportion of interventions from Conservative MPs (not including ministers) was similar to the party's proportion of (non-ministerial) seats. The proportion of Labour interventions was somewhat lower than their proportion of seats, ${ }^{22}$ while Liberal Democrat (LD) and the Scottish Nationalist Party (SNP) MPs tended to speak more than their proportion of seats would predict. The Liberal Democrats only have $11 \mathrm{MPs}$, but they were particularly active on China in 2020: four of the 11 are members of the Inter-Parliamentary Alliance on China (IPAC), which takes very critical positions in relation to China (see below), and two of the seven most active back-bench MPs on China in 2020 were Liberal Democrats. Those who spoke five times or more in 2020 (excluding government ministers and shadow ministers) were Iain Duncan Smith (Conservative, 9 times), Alistair Carmichael (LD, 8), Jim Shannon (Democratic Ulster Party, 8), Alyn Smith (SNP, 7), Tom Tugendhat (Conservative, 7), Bob Seely (Conservative, 6), and Layla Moran (LD, 5).

Two China-focused parliamentary groups were set up in 2020 and became prominent in policy debates and dissemination of views about China. The first, the China

\footnotetext{
21 It would be interesting to compare this with levels of engagement on other topics to see whether China attracted a similar proportion of parliamentarians to other regular topics.

22 A complicating factor here is that a number of Labour MPs have shadow ministerial portfolios which do not exclude them from speaking in debates on topics outside their portfolio, such as China (we found a few examples), but this may still reduce the likelihood that they will speak in such debates.
} 


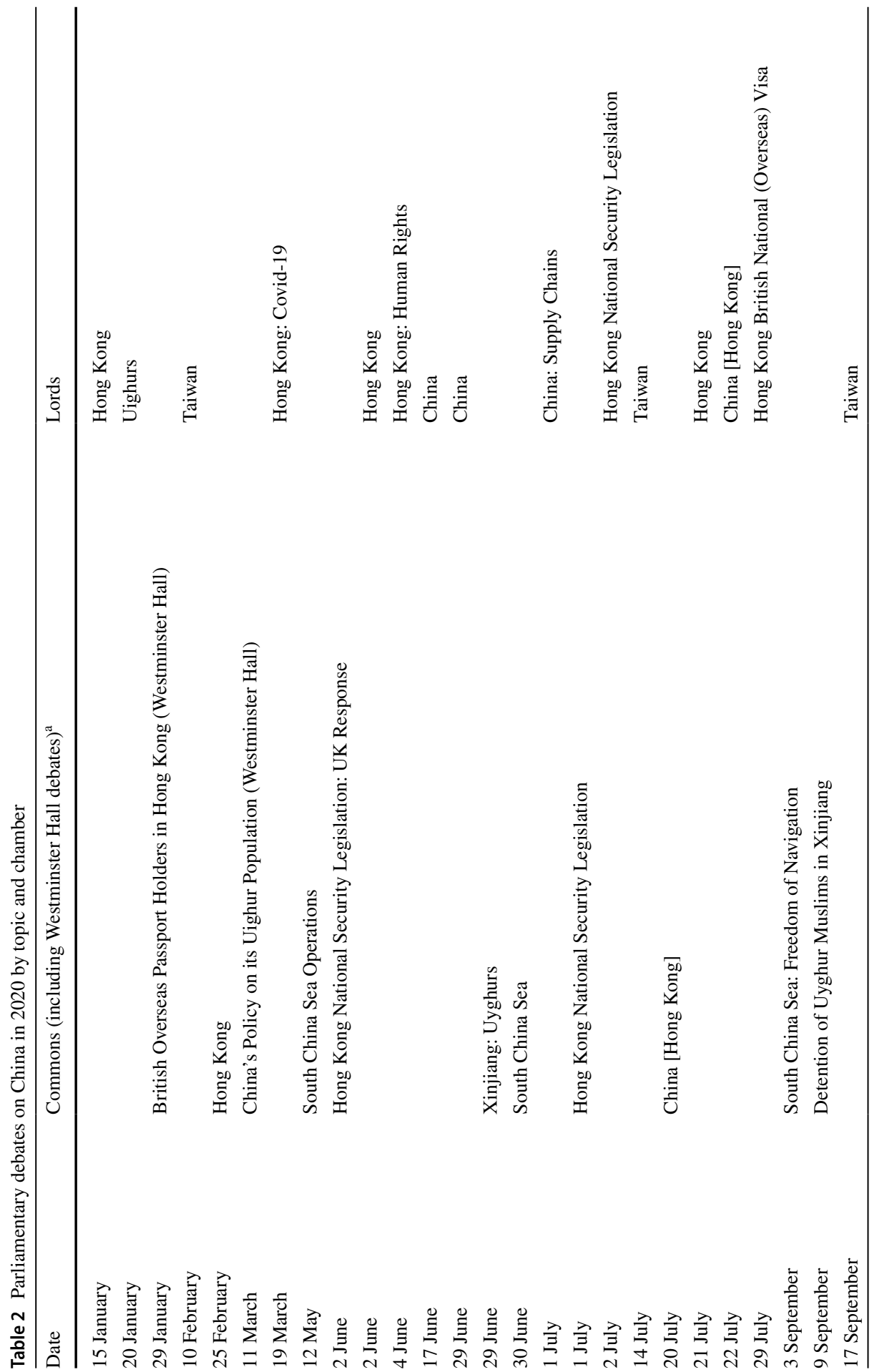




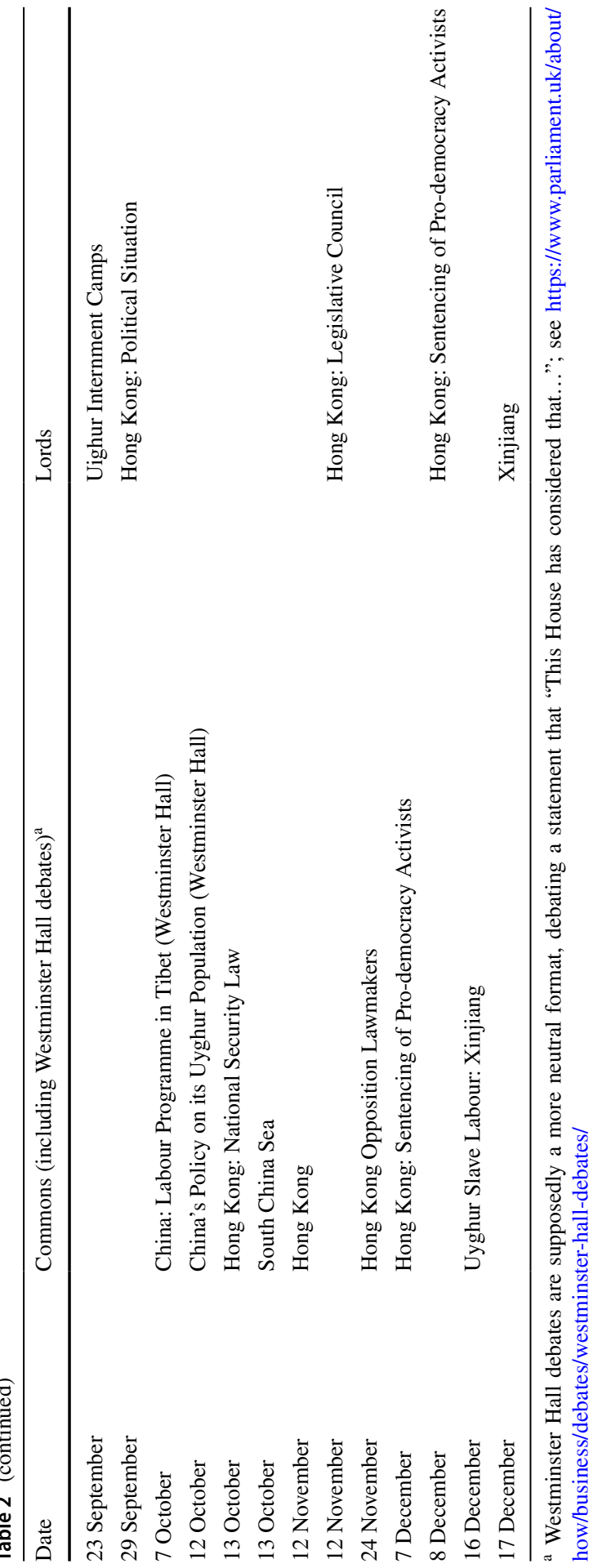


Research Group (CRG), was formed in April 2020 by Conservative Party members of parliament, led by Tom Tugendhat and Neil O'Brien (seven other MPs are on its committee). Its stated aims are to "promote debate and fresh thinking about how Britain should respond to the rise of China", with particular focus on Chinese foreign policy, industrial policy, and technology issues. As of May 2021, it employs two researchers. It has organised a number of online discussion events relating to China and published four reports in its first year, along with a daily and weekly newsletter distributed by email. ${ }^{23}$ While there are no similar groups in the Labour Party, "opposition leader Keir Starmer ... has sought to define a Labour Party position on China closer to that of [China Research Group's] Tugendhat than to those of [Prime Minister] Johnson and the previous coalition government" (McCourt 2021: 21).

The CRG is widely seen as advocating a more "hawkish" British policy towards China, though chair Tom Tugendhat has said that there are a range of views among the group members. Tugendhat himself has been the most prominent member of the group, and also chairs the Commons Foreign Affairs Committee. He was active in pushing the government to reconsider its Huawei policy, and has called for sanctions in response to developments in Hong Kong and Xinjiang. Tugendhat has said that the idea for setting up the CRG came out of work the FAC did on dealing with autocracies. ${ }^{24}$ Although a Conservative group, the CRG has recently made some effort to reach across the political aisle, hosting Labour foreign affairs spokesperson Lisa Nandy at one of its recent events.

The other group is the Inter-Parliamentary Alliance on China (IPAC), set up in June 2020. As of February 2021, it had 196 members from 18 national parliaments (nearly all Western countries) and the European Parliament. It is coordinated from the U.K., and 48 of its members, almost one quarter, are British parliamentarians, 43 in the Commons and five in the Lords. ${ }^{25}$ Half of these are Conservatives, 15 Labour and four Liberal Democrats. IPAC's lobbying has included campaigns focused on Hong Kong, Xinjiang, and Tibet, including through parliamentary debates. When the Chinese government responded to targeted British sanctions on four Chinese officials for "gross human rights violations in Xinjiang" in March 2021, the entire CRG (as a group), Tugendhat, O'Brien, and five active parliamentary members of IPAC were "sanctioned" by Beijing in return.

Both of these parliamentary groups have become widely quoted sources of views of China and how the British government should respond to it. Their predominantly unfavourable views of China, reinforced by the interventions of other parliamentarians during debates on China, likely shape broader British perceptions of China.

\footnotetext{
23 This material is based on the CRG website, available at https://chinaresearchgroup.org/ (accessed 21 May 2021).

24 Merics podcast, 4 June 2020, available at https://merics.org/en/podcast/british-mp-tom-tugendhatnew-china-research-group-we-need-understand-china-better

${ }^{25}$ Figures calculated from https://ipac.global/team/ (accessed 11 February 2021).
} 


\section{Media coverage of China in the UK}

Respondents to the Sinophone Borderlands survey were asked the frequency of their use of different sources of information on China, with 0 representing "not at all" and 10 "a lot". On average, British respondents relied the most on the media (the only category to average over 5), then politicians' statements, and then social media. Of the 1500 respondents, only $101(6.8 \%)$ said they had personally visited China. This suggests that most people form their perceptions of China based on "second-hand" information mediated through the media or other channels, rather than first-hand experience. Britons who had visited China $(N=101 ; M=43.23 ; \mathrm{SD}=27.48)$ were slightly more positive about China than those who had not. ${ }^{26}$

Respondents also named the main media sources from which they get information, giving us valuable data on which sources could be most relevant. While politicians' statements were identified as a source of information, we suggest that politicians are also socialised by the predominant sentiments in the media, complemented by reading the output of think tanks, lobby groups, or books more than for the general public. The positions they take based on that information will depend on a range of factors, including their political interests and perceptions of public views.

It seems reasonable to conclude from this that British media coverage of China is an important factor in the formation of public perceptions about China, and we expect to see some correlation between media framing of China and public views and those of the political elites. We tested this hypothesis at a broad level by doing some brief analysis of media coverage of political issues relating to China in 2020, building on existing literature on (British) media coverage and framing of China. ${ }^{27}$ Previous studies found that British daily press coverage of China around the Beijing Olympics in 2008 focused particularly on large-scale and dramatic events, with very few substantial articles in the tabloids, but the most popular titles (Sun and Daily Express) had more negative coverage (China as "one of the markers of a dangerous and threatening world") compared to the Financial Times with more nuanced coverage (Sparks 2010). Subsequently, Sparks (2015) looked at UK daily press coverage of the Hong Kong Occupy Central movement in 2014, showing how this coverage generally framed the movement as a legitimate response to authoritarian rule. Mawdsley (2008) examined coverage of China in Africa in the press in early 2000s, showing a tendency to "demonis[e] China and largely exculpat[e] the West" (2008: 525), framing China's influence as malevolent, with little critical reflection on the West's role in Africa. More recently, Turcsanyi and Kachlikova (2020) looked at

\footnotetext{
${ }^{26} N=1392 ; M=34.44 ; \mathrm{SD}=24.90, F_{1,1408}=9.088, p=.003, \eta_{p}{ }^{2}=.006$, controlling, for age, gender, and education levels. Although the two groups were vastly different in size, an insignificant Levine's test result revealed that the equality of variance assumption underlying ANCOVA was not violated, $F_{1,1491}=1.890, p=.169$.

${ }^{27}$ There are broader implications of this given the global reach of UK-based media. Commenting on the UK's influence in international debates, Chatham House Director Robin Niblett wrote in a recent paper that "The BBC, the Economist, the Financial Times, and the Guardian ... dominate reporting and commentary on international affairs" (2021: 17). According to the British government, the BBC World Service reaches 468 million people per week (HM Government 2021: 50).
} 
coverage of the Belt and Road Initiative put forward by Beijing from 2013 to 2017, showing that this was generally framed in the UK media as an economic initiative, less as a geopolitical one than in other European countries they studied.

To examine media coverage of China in 2020, we started with analysis of the "Big Reads" in the Financial Times. We select this newspaper because of its influence among political elites. ${ }^{28}$ The "Big Read" series offers almost daily in-depth analysis on a range of topics (308 articles in both 2020 and 2019) and had a considerable emphasis on China (35 articles in 2020, 34 in 2019), much more than articles on Brexit, for example. Written by regular Financial Times journalists, we contend that the way China is framed here reflects broader framing of China in the Financial Times. Based on a careful reading of all the pieces on China, our analysis shows a strongly dominant negative framing of China in these Big Reads. None of the 35 stories in this series in 2020 framed China in a positive way, while only four were neutral. This negative framing featured a number of repeated themes: China as authoritarian at home, aggressive overseas, with a problematic political system and political culture, all exacerbated under Xi. US-China rivalry was a major theme, with US policy in many pieces seen as justified response to actions by China. Xinjiang and Hong Kong featured as regular examples of the "problematic" nature of China today. Its overall framing of China was similar to that in the parliamentary debates of 2020.

In the Sinophone Borderlands survey, a particular BBC outlet or simply "the BBC" (note that the BBC is not a monolith) was named by 1160 (77\%) survey respondents as one of the "most important media" for them (respondents could name multiple outlets). We therefore did a framing analysis of 79 stories about China on the BBC website from 15 August to 1 November $2020 .{ }^{29}$ Of these stories, nine were coded positive, with 37 negative, and the remaining 33 neutral. Positive stories tended to be about the resilience or growth in the Chinese economy or technological developments.

It is worth noting that not only "British" publications are producing media content about China that is accessible in the UK. Chinese media have increasingly published in English via China Global Television Network (CGTN), the China Daily, Global Times, and Caixin, for example. So far, however, this coverage has not yet been influential in providing an alternative framing or representation of China in the UK's public debate, and even though some UK residents read their coverage, the number remains small. These China-related media outlets are labelled as "stateaffiliated media" on social media (such as YouTube or Twitter), which likely reduces their influence on public opinion in the UK. In the Sinophone Borderlands survey, a Chinese media outlet was mentioned by none of the respondents (Russia Today was mentioned by two). This suggests that coverage by the BBC is particularly important

\footnotetext{
${ }^{28}$ This follows Sparks (2010) in focusing on substantial articles, but rather than select these by number of references to China, we have taken this series in the Financial Times. The Financial Times is an "elite" publication, particularly influential politically and internationally.

29 We identified articles on www,bbc.com/news with keywords "China" or related terms such as "Taiwan", "Hong Kong", or "Xinjiang". We are grateful to Su Xinlu for her help in compiling these reports.
} 
and that the vast majority of British public tend to form their views of China based on familiar, British media outlets, rather than anything produced by Chinese organisations. While more work is needed to analyse other media, the findings of this preliminary survey of the British media landscape on China during 2020 indicate a predominantly critical framing of China, consistent with the survey results, parliamentary debates, and the shifts in government policy during 2020.

\section{Conclusion}

This paper has shown that British public and political perceptions of China in 2020 were predominantly negative and had deteriorated significantly over the previous few years. This was demonstrated in data collected from the Sinophone Borderlands survey carried out in September and October 2020, which showed around two-thirds of respondents had "negative" perceptions of China while a similar number claimed that their views of China got worse over the previous three years. The survey results suggest that Covid-19 was important in explaining the negative perceptions, but also that views about other issues relating to China's foreign policy, political system, and concerns about human rights, as well as reservations about economic engagement with China were significant factors in negative perceptions. During 2020, these negative views were reflected in other major domains: discussion of China in parliament was almost universally negative, while a brief review of British media coverage suggests it too was dominated by negative framings of China. Given that the Sinophone Borderlands survey results suggest media and politicians are particularly important in informing public perceptions of China, the trends in these three domains could be self-reinforcing. ${ }^{30}$

Growing negative perceptions of China coincided with a shift in the British government's approach to China from a broad embrace at the start of the so-called "golden era" in 2015 to a more sceptical approach over subsequent years (Summers 2021a), and a further deterioration in 2020 and into 2021 during the Covid-19 pandemic. Parliament and the lobby groups within and around it were more prominent in the policy debates. ${ }^{31}$ For example, one reason for the Johnson government's volte face on Huawei in the middle of 2020 was the prospect of losing a parliamentary vote on the issue, alongside growing expression of concerns about Huawei in reports by advocacy groups such as The Henry Jackson Society (Seely et al 2019). In March 2021, the government also responded to prolonged parliamentary (and media) pressure on Xinjiang by sanctioning four Chinese officials, though the harsher Chinese

\footnotetext{
${ }^{30}$ Further research is needed to ascertain whether media reports of public opinion surveys about China in 2020 further contributed to a "feedback loop" through which coverage of their findings strengthened negative perceptions of China.

31 Aside from IPAC and CRG (covered above), another prominent group is Hong Kong Watch, whose advocacy strays beyond Hong Kong to wider China and human rights issues.
} 
counter-sanctions mean that any pain is probably felt more on the UK side than by the Chinese government. ${ }^{32}$ The granting of a "pathway to citizenship" for those in Hong Kong who hold British National (Overseas) passports and their dependents was in large part the result of lobbying by parliamentarians and the advocacy group, Hong Kong Watch (Summers 2021b). These examples show the extent to which parliamentarians and lobby groups have played a role in setting the agenda for the UK's China policy.

The government's approach has, however, stopped short of the comprehensive framing in the US of China as an urgent "strategic challenge", as British leaders "fear the downturn in relations with China portended by an era of Great Power competition" (McCourt 2021: 23). The Integrated Review suggests that-as of March 2021 - the government wanted to retain space for engagement with China, in economic areas as well as in global issues. This is in contrast to the vociferous criticism of China from parliament and calls for a much harsher policy turn from the China Research Group, IPAC, and the Labour party's shadow foreign affairs team. This raises a number of policy questions about how well the public debate about China in the UK reflects the complex reality of China today and whether there is space to facilitate a more balanced space for public debate about China in the UK. At the moment, however, the widespread negative views about China among the public and in political circles will constrain UK-China relations from developing in a more positive direction.

Public opinion matters. One of the consequences of the connection being made between China and the outbreak of Covid-19 has been a rise in prejudice or hate crimes against the Chinese/Asian community in the UK. This has also occurred in other western countries such as the USA and Australia where there is a large Chinese community. ${ }^{33}$ Chinese students, academics, and professionals in the UK have been assaulted (Khan 2021), with reports that "UK police data suggests a rise of $300 \%$ in hate crimes towards Chinese and East and Southeast Asians in the first quarter of 2020 compared with the same periods in 2018 and 2019" (Matsuda 2021). Whereas discrimination towards the Chinese community is arguably the worst since the Cold War, the difference now is that the Chinese community has a better social status than decades ago, and they are in a better position to speak out and counter hate crimes. For example, several campaigns have been organised by citizens to tackle hate crimes toward the Asian communities since the beginning of 2020, and petitions were submitted to Parliament to increase awareness among MPs. More recently, British-Chinese public figures such as Gemma Chan have launched an initiative to tackle hate crimes towards East and Southeast Asian communities (Ramachandran 2021). These

\footnotetext{
32 The British MPs sanctioned have sought to wear this as a badge of pride, with a number (though not all) of them getting a meeting and photo opportunity with the Prime Minister as a result. The more serious impact has been on Essex Court Chambers, a barristers set which was included in the Chinese sanctions list because it had published on its website an Opinion on the question of genocide in Xinjiang. A number of barristers have since left the chambers. See Financial Times, UK lawyers feel ripples of Chinese sanctions on Essex Court Chambers, 5 April 2021.

${ }^{33}$ Looking at discourse in Germany, Han and Marwecki (2020) have recently argued that racial prejudice in the West is part of the "ideational foundation" for perceptions of China's rise.
} 
voices make a difference in challenging the worsening public opinion while attempting to prevent further hate crimes. However, these voices are still marginal compared to the popular perception of China and by extension Chinese in the UK. The worsening perceptions by Britons towards China could extend to a worsening perception toward the Chinese community (which includes old and new immigrants as well as British Chinese). Limited parliamentary attention towards this ethnic minority in the UK is a separate issue, but it has indeed been overshadowed by the debates in the context of foreign relations as mentioned above.

Finally, this paper points to a number of avenues for further research. One is to look more systematically at the "transition mechanisms" through which perceptions are formed and used to influence foreign policy formation, building on existing literature on framing and narratives. A second area would be to analyse further material from the government itself, going beyond ministerial statements to social media postings by British diplomats in China or government departments beyond the foreign ministry, for example, some of which highlight areas for engagement with China more than the mainstream policy debates in London. The impact of these ongoing efforts to promote connections across trade, investment, culture, and education needs to be further integrated into studies of British policy towards China and the public debates around that policy. Another area for more research is how the British-Chinese community and Chinese students in the UK are affected by the worsening perceptions of China in the UK and their efforts to respond to these perceptions, and how well the government ensures a safe and welcoming environment for Chinese students and tourists, who have become a major source of income and soft power for the UK. A final area for further study is the impact on public opinion and perceptions of Chinese experiments with different diplomatic and social media strategies (Gries and Turcsanyi 2021; Jerdén et al 2021) as well as the work of NGOs.

Funding The work was supported by the European Regional Development Fund Project "Sinophone Borderlands-Interaction at the Edges", CZ.02.1.01/0.0/0.0/16_019/0000791. Survey approved by Palacky University Olomouc ethnics committee.

The authors declare no competing interests.

\section{References}

Breslin S (2004) Beyond diplomacy? UK relations with China since 1997. BJPIR 6:409-425

British Foreign Policy Group (2021) Annual survey of UK public opinion on foreign policy and global Britain. https://bfpg.co.uk/2021/02/2021-annual-survey/

Brown K (2019) The future of UK-China relations. Agenda Publishing, Newcastle upon Tyne

Brown K (2011) Britain's relations with China under new labour: engagement and repulsion? In: Daddow O, Gaskarth J (eds) British Foreign Policy: The New Labour Years. Springer, pp 170-187

Brown SAW (2018a) Free trade, yes; ideology, not so much: the UK's shifting China policy 2010-16. J Br Assoc Chin Stud 8(1):92-126

Brown SAW (2018b) Power, perception and foreign policymaking. Routledge, London and New York

Chow W, Han E, Li X (2019) Brexit identities and British public opinion on China. Int Aff 95(6):1369-1387

Cohen J (1988) Statistical power analysis for the behavioral sciences. Lawrence Erlbaum, Mahwah 
Foreign Affairs Committee (2020) Viral immunity: The FCO's role in building a coalition against COVID-19. https://publications.parliament.uk/pa/cm5801/cmselect/cmfaff/239/23903.htm\#_idTex tAnchor000

Gries P (2014) The politics of American foreign policy: how ideology divides liberals and conservatives over foreign affairs. Stanford University Press, Stanford

Gries P, Turcsanyi R (2021) Chinese pride and European prejudice: how growing resentment of China cools feelings toward Chinese in Europe. Asian Surv. https://doi.org/10.1525/as.2021.1397345

Han E, Marwecki D (2020) Racialized international order? Traces of 'yellow peril' trope in Germany's public discourse toward China. Camb Rev Int Aff. https://doi.org/10.1080/09557571.2020.1864296

Harris P (2017) China in British politics: western unexceptionalism in the shadow of China's rise. Chin J Int Polit 10(3):241-267

Henderson M, Mendoza A, Foxall A, Rogers J, Armstrong S (2020) Coronavirus compensation: assessing China's potential culpability and avenues of legal response. The Henry Jackson Society. https:// henryjacksonsociety.org/publications/coronaviruscompensation/

HM Government (2021) Global Britain in a competitive age: the integrated review of security, defence, development, and foreign policy. https://assets.publishing.service.gov.uk/government/uploads/system/uploads/attachment_data/file/969402/The_Integrated_Review_of_Security__Defence_Devel opment_and_Foreign_Policy.pdf

Irwin Crookes P, Farnell J (2019) The UK's strategic partnership with China beyond Brexit: economic opportunities facing political constraints. J Curr Chin Aff 48(1):106-121

Jerdén B, Rühlig T, Seaman J, Turcsányi R (2021) Chinese public diplomacy and European public opinion during COVID-19. Chin Rev 21(2):5-34

Khan A (2021) "I don't feel safe": Asians in the UK reflect on a year of hatred. Aljazeera, 23 March 2021. https://www.aljazeera.com/news/2021/3/23/i-dont-feel-safe-asians-in-the-uk-reflect-on-ayear-of-hatred. Accessed 17 June 2021

Mackerras C (1987) Western images of China. Oxford University Press, Oxford

Mark C (2017) The everyday Cold War: Britain and China, 1950-1972. Bloomsbury

Matsuda T (2021) It's time to talk about anti-Asian racism in the UK. Aljazeera, 1 April 2021. https:// www.aljazeera.com/opinions/2021/4/1/its-time-to-talk-about-anti-asian-racism-in-the-uk. Accessed 20 May 2021

Mawdsley E (2008) Fu Manchu versus Dr Livingstone in the Dark Continent? Representing China, Africa and the West in British broadsheet newspapers. Polit Geogr 27:509-529

McCourt D (2021) Framing China's rise in the United States, Australia and the United Kingdom Int Aff https://doi.org/10.1093/ia/iiab009

Niblett R (2021) Global Britain, Global Broker. Chatham House, London. https://www.chathamhouse. org/2021/01/global-britain-global-broker. Accessed 16 June 2021

Silver L, Devlin K, Huang C (2020) Unfavorable views of China reach historic highs in many countries. Pew Research Center, Washington, DC. https://www.pewresearch.org/global/2020/10/06/unfavorable-views-of-china-reach-historic-highs-in-many-countries/

Patten C (2020) China's nasty, lying, bullying communist regime must face judgement over coronavirus. Mail on Sunday

Seely B, Varnish P, Hemmings J (2019) Defending our data: Huawei, 5G and the five eyes. Henry Jackson Society. https://henryjacksonsociety.org/publications/defendingourdata/

Sparks C (2010) Coverage of China in the UK national press. Chin J Commun 3(3):347-365

Sparks C (2015) Business as usual: the UK national daily press and the Occupy Central movement. Chin J Commun 8(4):429-446

Summers T (2019) The UK's China policy under US-China strategic rivalry: the impact of think tank research. Chin Q Int Strateg Stud 5(2):177-196

Summers T (2021a) Imagining Brexit: the UK's China policy after the referendum. In: Reilly M, Lee C-Y (eds) A new beginning or more of the same? The European Union and East Asia After Brexit. Palgrave Macmillan

Summers T (2021b) Britain and Hong Kong: the 2019 protests and their aftermath. Asian Educ Dev Stud. https://doi.org/10.1108/AEDS-09-2020-0205)

Ramachandran N (2021) Gemma Chan, Henry Golding Back U.K. 'Stop Asian Hate' Initiative. Variety. 10 May 2021. https://variety.com/2021/film/news/gemma-chan-henry-golding-stop-asian-hate-uk1234969627/. Accessed 20 May 2021

Turcsanyi R, Kachlikova E (2020) The BRI and China's soft power in Europe: why Chinese narratives (Initially) won. J Curr Chin Aff. https://doi.org/10.1177/1868102620963134 
Turcsányi R et al (2020) Sinophone Borderlands Europe Survey. Palacky University Olomouc

YouGov (2020) Do you see China becoming a superpower as more of a threat or an opportunity for Britain, or neither? https://yougov.co.uk/topics/science/survey-results/daily/2020/05/19/b9b94/1

Publisher's Note Springer Nature remains neutral with regard to jurisdictional claims in published maps and institutional affiliations. 